\title{
A new species of Dischidia (Apocynaceae, Asclepiadoideae) from North-eastern Thailand
}

\author{
Wilawan Promprom', Wannachai Chatan' \\ I Department of Biology, Faculty of Science, Mahasarakham University, Kantharawichai District, Mahasa- \\ rakham Province, 44150, Thailand \\ Corresponding author: Wannachai Chatan (wannachaichatan@gmail.com)
}

Academic editor: Peter Bruyns | Received 3 November 2019 | Accepted 13 February 2020 | Published 17 March 2020

Citation: Promprom W, Chatan W (2020) A new species of Dischidia (Apocynaceae, Asclepiadoideae) from Northeastern Thailand. PhytoKeys 144: 23-30. https://doi.org/10.3897/phytokeys.144.47977

\begin{abstract}
Dischidia phuphanensis Chatan \& Promprom, a new species from north-eastern Thailand, is described and illustrated. The new species is similar to D. tonkinensis Costantin, but is distinguished by the shape of its leaves, the apices of the staminal corona lobes, the colour of the corolla and the absence of a corolline corona. The distinguishing characters of similar species are discussed. A key for the identification of those species in Thailand without pitcher-like leaves is provided.
\end{abstract}

\section{Keywords}

Marsdenieae, plant diversity, taxonomy

\section{Introduction}

Dischidia Brown (1810: 461) belongs to the tribe Marsdenieae of the Apocynaceae and comprises approximately eighty species, distributed in India, Indochina, Malesia, Melanesia and the eastern Pacific (Rintz 1980; Livshultz et al. 2005). Some members of Dischidia are epiphytes living in association with ants (Livshultz et al. 2005; Kidyoo and Suddee 2017). Ants may inhabit the pitcher-shaped leaves of certain species or they may live in the shelter of those with circular leaves which are convex above and concave below. Dischidia exhibits umbel-like inflorescences with small, more or less urceolate flowers that usually have a ring of hairs inside the mouth of the corolla tube and an anchor-shaped staminal corona (Rintz 1980, Forster 1996, Hoffmann et al. 2002). 
In Thailand, nineteen species of Dischidia were reported by Thaithong et al. (2018). During a floristic survey of the forests in north-eastern Thailand conducted between 2009 and 2018, specimens of Dischidia were collected in Sakon Nakhon Province. After the living plants and herbarium specimens were carefully investigated, the authors concluded that these could not be referred to any previously named species. Consequently, a new species, D. phuphanensis, is described here.

\section{Material and methods}

Specimens were collected from Phu Pha Yol National Park, Sakon Nakhon Province, Thailand in 2017. Morphological observations of the new species were carried out on living plants from the field, as well as on herbarium specimens in BK and BKF. Measurements were made with a Vernier caliper or with an ocular micrometer in a dissecting microscope. We consulted the relevant taxonomic literature (e.g. Kerr (1951), Kidyoo and Suddee (2017), Thaithong et al. (2018) etc). We assessed the preliminary conservation status of the new species using our field knowledge and by applying the criteria given by IUCN (2017).

\section{Taxonomy}

Dischidia phuphanensis Chatan \& Promprom, sp. nov. urn:Isid:ipni.org:names:77208268-1

Figures 1, 2

Diagnosis. Dischidia phuphanensis is most similar to D. tonkinensis, but the new species differs from the latter in its elliptic or narrowly elliptic or slightly oblanceolate leaves (leaves in $D$. tonkinensis are ovate to ovate elliptic, rarely obovate), apex of corona lobes obtuse (with tips pointing downward in D. tonkinensis), yellow base of the corolla tube and light yellow or white apices of the lobes (white or orange-yellow corolla tube and lobes in D. tonkinensis) and the absence of a corolline corona (corolline corona present in D. tonkinensis). (Figures 1,2)

Type. Thailand: Sakon Nakhon Province, Phu Pha Yol National Park, 300-400 m, $16^{\circ} 56.126667^{\prime} \mathrm{N}, 104^{\circ} 2.336667^{\prime} \mathrm{E}, 7$ August 2017, W. Chatan 2489 (holotype: BKF!; isotype: BK!).

Description. Plant epiphytic or lithophytic, sometimes pendulous, fleshy, growing loosely rooted on the host trees or shrubs or on rocks, glabrous except in tube of corolla. Branches terete, 2.0-2.5 mm thick, green or greenish-purple; internodes 5-15 cm long. Stipular colleters paired, triangular, ca. $0.1 \mathrm{~mm}$ long. Leaves with cylindrical (slightly flattened above), $7-13 \times 2.0-2.3 \mathrm{~mm}$ petiole; lamina green, dark green or purplish-green, underneath lighter green, slightly fleshy and coriaceous, elliptic, narrowly elliptic or slightly oblanceolate, $3-5 \times 1.5-2.0 \mathrm{~cm}$, apex acute-apiculate, base 


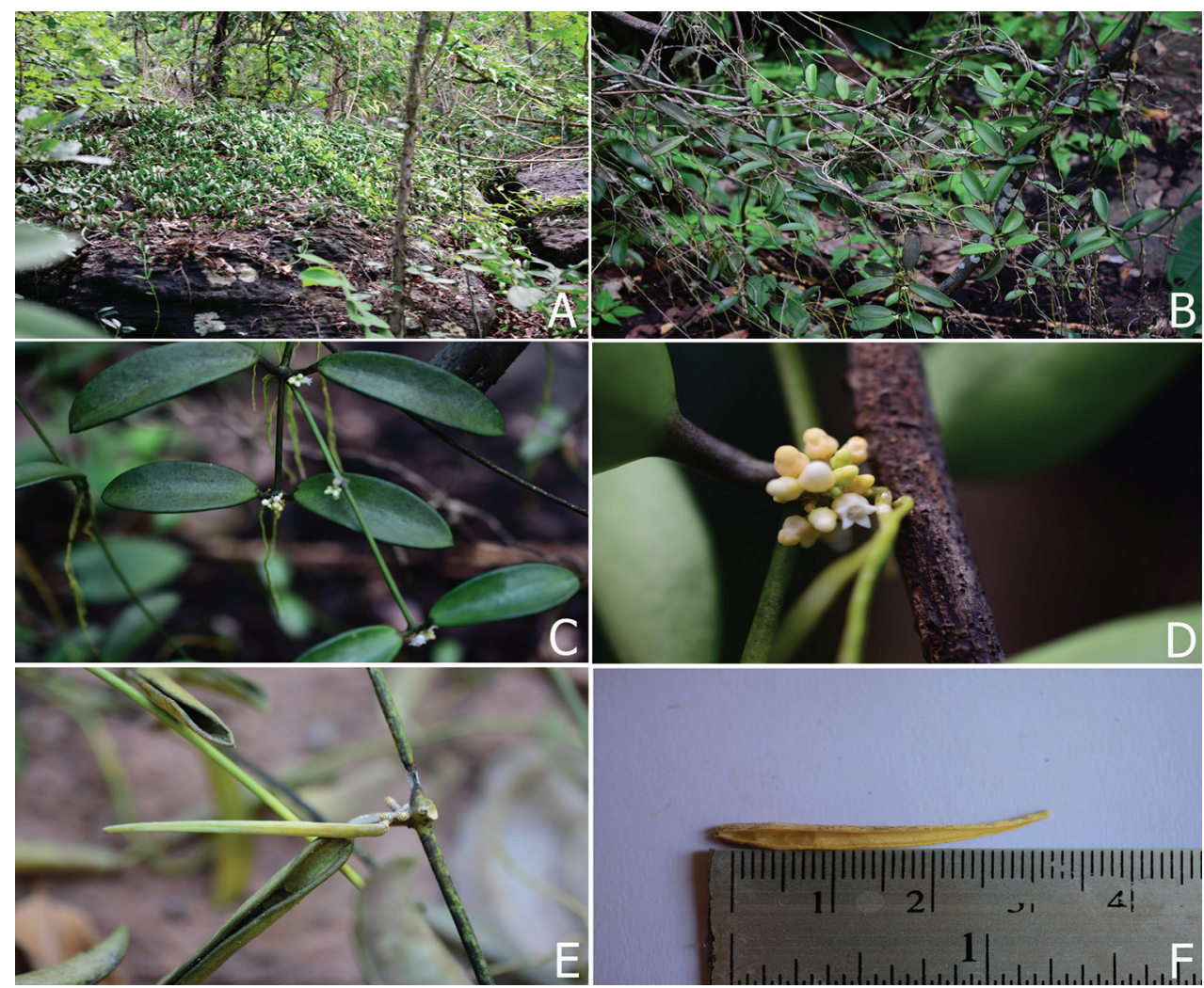

Figure I. Dischidia phuphanensis. A Plant climbing on rock B plant climbing on branches of shrub 2-3 $\mathrm{m}$ tall $\mathbf{C}$ branches and leaves $\mathbf{D}$ inflorescence $\mathbf{E}$ follicle (nearly mature) F dehiscent follicle. Photographed by Wannachai Chatan from W. Chatan 2489 (A-D) and W. Chatan 2904 (E, F).

round or slightly acute, margin entire, gland present on adaxial side near lamina base, midrib and secondary veins inconspicuous on both surfaces. Inflorescences umbelliform, usually bearing $1-4$ open flowers and $2-5$ developing buds; bracts 2 subtending each flower, triangular, ca. $0.5 \times 0.5 \mathrm{~mm}$, greenish-brown, apex acute; peduncle extraaxillary or apparently axillary, persistent, $0-3 \mathrm{~mm}$ long; rachis $1-5$ per peduncle, bearing scars of previous flowerings $1-3 \times 1.0-1.8 \mathrm{~mm}$; pedicels $1-2 \times \pm 0.5 \mathrm{~mm}$. Sepals greenish-white, lobes ovate, $0.6-0.8 \times 0.5-0.8 \mathrm{~mm}$, apex round, without colleters. Corolla broadly urceolate or slightly globose, $2.4-2.6 \times 2.4-2.5 \mathrm{~mm}$, basally yellow, progressively fading into light yellow or white at the tips of the lobe, corolla tube with one ring of retrorse hairs in throat; lobes triangular to deltate, light yellow or white, $1.3-1.5 \times$ ca. $1.3 \mathrm{~mm}$, apex acute; corolline corona absent. Gynostegium conical in outline, $1.8-2.0 \mathrm{~mm}$ tall, $1.4-1.6 \mathrm{~mm}$ in diameter. subsessile; stipe ca. $0.1 \mathrm{~mm}$ tall. Staminal corona lobes anchor-shaped, stalk ca. $0.8 \mathrm{~mm}$ high, apical part ca. $0.6 \times$ $0.8 \mathrm{~mm}$, apex obtuse. Pollinarium erect, ca. $2 \mathrm{~mm}$ long. Pollinium yellow, $0.6-0.8 \times$ $0.20-0.22 \mathrm{~mm}$, ellipsoidal; translator arms $1.0-1.2 \mathrm{~mm}$ long; corpusculum ovate, 


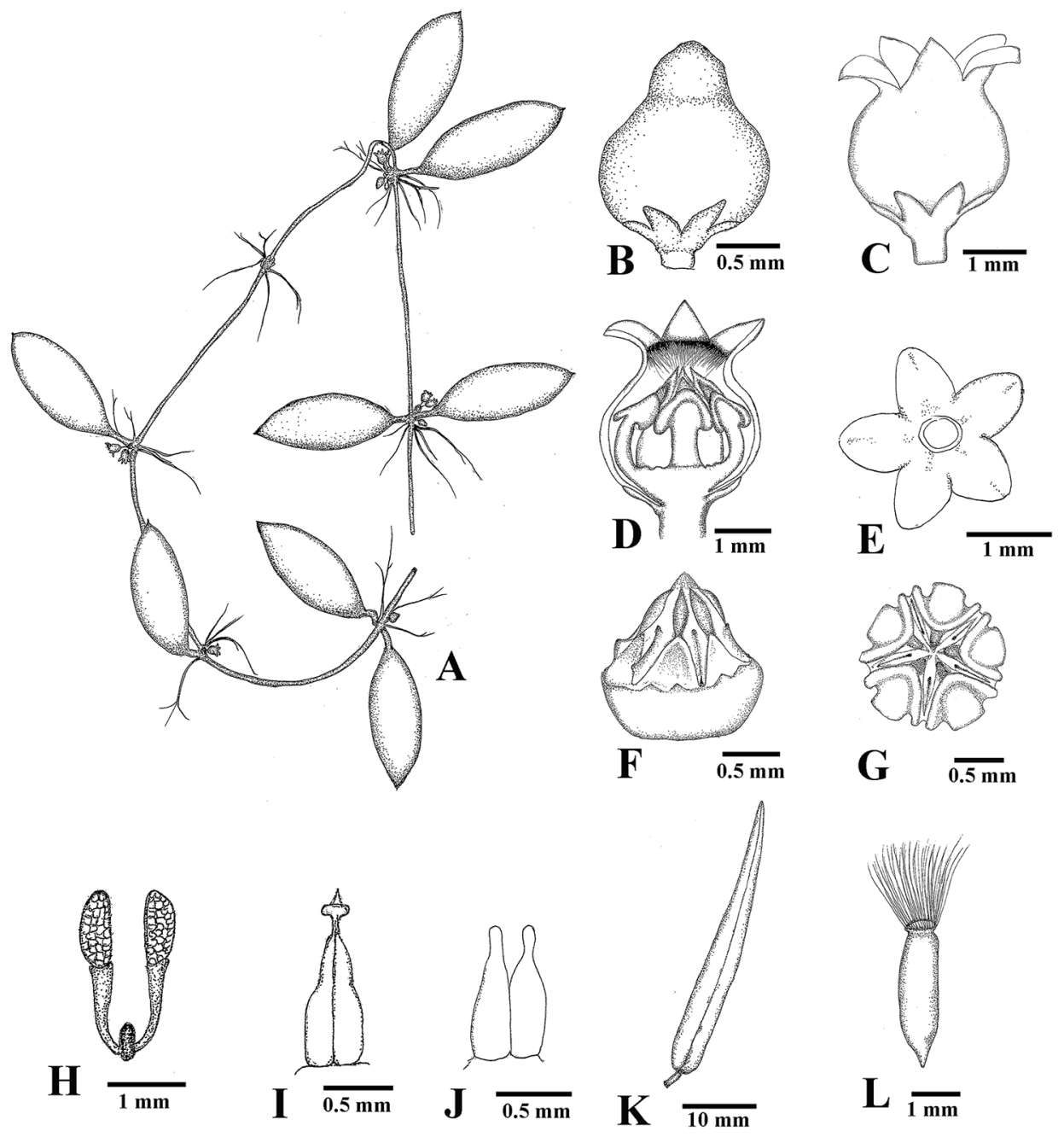

Figure 2. Dischidia phuphanensis. A Branch with leaves and inflorescences B bud C flower D dissected flower with half of corolla removed $\mathbf{E}$ calyx from abaxial side $\mathbf{F}$ gynostegium (side view), with coronal lobes removed $\mathbf{G}$ gynostegium (from above) $\mathbf{H}$ pollinarium $\mathbf{I}$ pistil $\mathbf{J}$ pistil (style-head removed) $\mathbf{K}$ follicle L seed A-J drawn by Wannachai Chatan from W. Chatan 2489, and K, L from W. Chatan 2904.

reddish-brown, $0.15-0.16 \times 0.05-0.07 \mathrm{~mm}$. Ovary bicarpellate, bottle-shaped and slightly flattened, $0.7-1.0 \mathrm{~mm}$ long, each carpel ca. $0.2-0.5 \mathrm{~mm}$ in basal diameter. Follicles solitary by abortion. linear, $38-45 \times 2.5-3.0 \mathrm{~mm}$, green when immature changing to brown when ripe. Seed slightly cylindrical, $3.8-4.0 \times 1.3-1.5 \mathrm{~mm}$, base obconic, bearing white coma 30-32 mm long.

Additional specimen examined. Thailand, Sakon Nakhon Province: Phu Pha Yol National Park, 300-400 m alt., 1656'07.2"N, 10402'21.1"E, 5 September 2017, W. Chatan 2904 (paratype: BKF). 


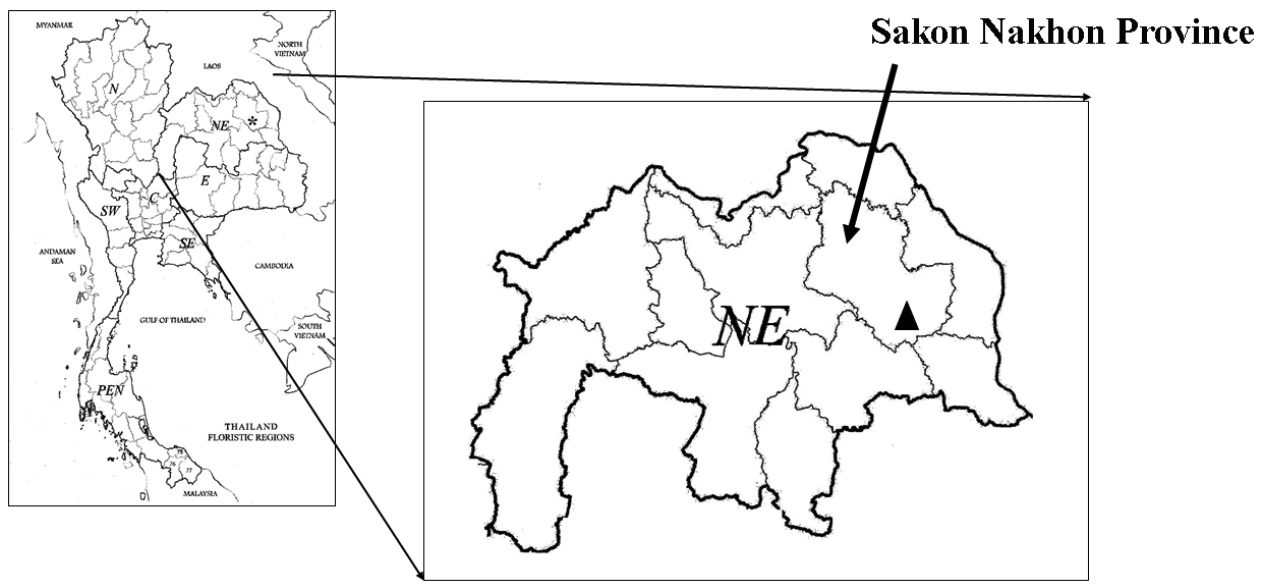

Figure 3. Distribution of Dischidia phuphanensis (black triangle) in Phu Pha Yol National Park, Sakon Nakhon Province, Thailand.

Phenology. Flowering in July-September and fruiting in Aug-December.

Distribution. The new species is endemic to Thailand and is known only from the type locality, Phu Pha Yol National Park, Sakon Nakhon Province, north-eastern Thailand (Figure 3).

Ecology. This new species grows in both slightly open and in shaded areas in mixed deciduous forest at an elevation of 300-400 m.

Vernacular name. Thao Rag Noi.

Etymology. The specific epithet of Dischidia phuphanensis refers to its type locality, the Phuphan mountain range.

Preliminary conservation status. One population of Dischidia phuphanensis was found at the type locality in Phu Pha Yol National Park, Sakon Nakhon Province, north-east Thailand. It is estimated to number fewer than 250 mature individuals. Therefore, it should be considered as "Endangered (EN)" according to the IUCN criteria D (IUCN 2017).

Discussion. Dischidia phuphanensis is similar to D. tonkinensis, from China, Indochina and Thailand (Thaithong et al. 2018). Similarities include their stems (thick, succulent, 2-3 $\mathrm{mm}$ in diameter, glabrous), glabrous petiole and lamina, succulent and coriaceous leaves and their glabrous corolla lobes. However, the new species differs from $D$. tonkinensis in its elliptic or narrowly elliptic or slightly oblanceolate leaves, the obtuse apex of the staminal corona lobes, the yellow base of the corolla tube, the light yellow or white apices of the lobes and absence of a corolline corona. Dischidia tonkinensis has ovate to ovate-elliptic, or rarely obovate lamina, the apices of the staminal corona lobes are retuse; it has a white or orange-yellow corolla tube and lobes and possesses a corolline corona. The new species is similar to D. acuminata Costantin, from Vietnam, in that they share the 1-5 branches to the inflorescence, the short peduncle $0-3 \mathrm{~mm}$ long and the absence of a corolline corona. It differs from $D$. acuminata by 
Table I. Distinguishing features between Dischidia phuphanensis and D. tonkinensis.

\begin{tabular}{lcc}
\hline \multicolumn{1}{c}{ Characters } & D. phuphanensis & D. tonkinensis \\
\hline 1. Leaf shape & $\begin{array}{c}\text { elliptic or narrowly elliptic or slightly } \\
\text { oblanceolate }\end{array}$ & ovate to ovate-elliptic, rarely obovate \\
2. Corolla colour outside & $\begin{array}{c}\text { tube yellow at base, light yellow or white } \\
\text { towards apices of lobes }\end{array}$ & white or orange-yellow tube and lobes \\
$\begin{array}{l}\text { 3. Corolline corona } \\
\text { 4. Staminal corona lobes }\end{array}$ & Absent & present \\
\hline
\end{tabular}

the triangular to deltate corolla lobes and with acute apices (narrowly shape, thick and abaxial side nose-like in D. acuminata (Constantin 1912))

The genus Dischidia may be divided into two main groups based on the leaf types, i.e. those with pitcher-like leaves and species with non-pitcher-like leaves. Dischidia phuphanensis has non-pitcher-like leaves. The most recent revision of Dischidia in Thailand was by Thaithong et al. (2018) and nineteen species were recognised. This was made up of one species with pitcher-like leaves and 18 species with nonpitcher-like leaves. After this new species is added to this group, the number of species with non-pitcher-like leaves is 19. A key to the species with non-pitcher-like leaves in Thailand is provided below and is modified from Thaithong et al. (2018). Details of the morphological differences between D. phuphanensis and D. tonkinensis are presented in Table1.

\section{Key to species of Dischidia with non-pitcher-like leaves in Thailand}

1 Leaves broadly ovate or orbicular or orbicular-peltate; if elliptic, then mixed with others that are peltate or orbicular.........................................................2

- Leaves narrowly ovate, elliptic, narrowly elliptic, obovate, lanceolate, oblanceolate, or spathulate; not mixed with peltate or orbicular leaves..................5

2 Leaves broadly ovate or orbicular or elliptic, abaxial sides slightly flattened...

D. nummularia

- $\quad$ Leaves peltate or orbicular, abaxial sides distinctly concave; 3

3 Branches pubescent

D. astephana

- Branches glabrous 4

$4 \quad$ Staminal corona lobes \pm absent

D. imbricata

Staminal corona lobes consisting of spreading horn-like projections

D. cornuta

Leaves abruptly laterally expanded at the middle or in upper half

D. singularis

6 Leaves linear or narrowly elliptic or spathulate; proportion of length /width is $3.8-16$ D. bengalensis

- Leaves ovate, elliptic, lanceolate, obovate, slightly oblanceolate or broadly obovate; proportion of length/width ratio smaller than 3.8 
7 Leaves broadly obovate, rarely elliptic; staminal corona lobes broadly saddleshaped

D. griffithii

- $\quad$ Leaves ovate, elliptic, slightly elliptic, lanceolate, slightly oblanceolate; staminal corona lobes anchor shaped or sagittate or reduced to minute swellings ..........8 Branches pubescent, tomentose or hirsute. 9

Branches glabrous

Corolla pink, red, dark red or purple, 6-7 mm long, with two rings of hairs inside around mouth of tube

D. hirsuta

Corolla white or creamy white, less than $5.5 \mathrm{~mm}$ long, mouth of corolla tube glabrous or with a single ring of hairs

Corolla ribbed inside; apices of corona lobes sagittate

D. rimicola

Corolla smooth inside; apices of corona lobes cuneiform

D. tomentella

Staminal corona lobes reduced to minute swellings

D. kerrii

Staminal corona lobes stalked and anchor-shaped or sagittate

12

Branches and leaves succulent

Branches and leaves not succulent.....

14

13 Apices of staminal corona lobes obtuse Apices of staminal corona lobes retuse.

D. phuphanensis

Corolla tube and lobes glabrous inside

D. tonkinensis

Corolla with hairs at mouth of tube or on adaxial side of lobes

D. calva

Leaves $1.5-3.0 \times 0.7-1.3 \mathrm{~cm}$; corona lobes anchor-shaped with rounded apices.

D. tricholoba

Leaves $2.5-6.5 \times 0.9-2.5 \mathrm{~cm}$; corona lobes sagittate with obtuse or truncate apices

D. singularis

Corolla greenish-white with purple lines alternating with lobes, mouth of corolla tube hairy throughout

D. punctate

Corolla white or creamy white, with a ring of hairs in mouth of tube

D. acutifolia

\section{Acknowledgements}

The authors thank the herbaria $\mathrm{BK}, \mathrm{BKF}$ and $\mathrm{K}$ for providing information on the type specimens for this study. We thank the officers in Phu Pha Yon National Park for help while collecting plant specimens on field trips. Thanks for linguistic advice from Dr. Adrian Roderick Plant, Mahasarakham University. Thanks for valuable comments and suggestions from the editor and reviewers. This research project was financially supported by Mahasarakham University (Fast Track 2020). 


\section{References}

Brown R (1810) Prodromus Florae Novae Hollandiae et Insulae Van-Diemen etc. Leonard Schrag, Nuremberg, 1-460. https://doi.org/10.5962/bhl.title.3678

Constantin J (1912) Dischidia R. Br. In: Lecomte MH (Ed.) Flora Generale de L' Indo-Chine, Volume 4. Masson Masson Et Ce, E’ Diteurs, Paris, 141-149.

Forster PI (1996) Asclepiadaceae. In: Robertson R, et al. (Eds) Flora of Australia, Volume 28, Gentianales. CSIRO, Melbourne, 197-307.

Hoffmann C, Van Donkelaar R, Albers F (2002) Dischidia R. Br. In: Albers F, Meve U (Eds) Illustrated handbook of succulent plants: Asclepiadaceae. Springer-Verlag Berlin Heidelberg, New York, 118-123.

IUCN (2017) Guidelines for using the IUCN red list categories and criteria, version 13. https://www.iucnredlist.org/ [accessed: 29 Aug 2018]

Kerr AFG (1951) Dischidia R. Br. In: Pendleton RL (Ed.) Florae Siamensis Enumeratio, Volume 3. Siam Society, Bangkok, 42-49.

Kidyoo M, Suddee S (2017) Dischidia kerrii sp. nov. (Apocynaceae: Asclepiadoideae) from northeastern Thailand. Nordic Journal of Botany 35(2): 185-188. https://doi.org/10.1111/ njb.01334

Livshultz T, Tran TB, Bounphanmy S, Schott D (2005) Dischidia (Apocynaceae, Asclepiadoideae) in Laos and Vietnam. Blumea 50(1): 113-134. https://doi.org/10.3767/000651905X623300

Rintz RE (1980) The Peninsular Malayan species of Dischidia (Asclepiadaceae). Blumea 26: 81-126.

Thaithong O, Kidyoo A, Kidyoo M (2018) Handbook of Asclepiads of Thailand. Amarin Printing and Publishing Public Company Limited, Thailand, 1-326. 